Jelena V. Grubor

Department of Philology, English Language and Literature Study Programme State University of Novi Pazar, Serbia bram.english@yahoo.co.uk

\title{
The Cultural Dimension of SLA: Attitudes of Philological and Non-Philological Learners to English Language Speakers
}

\begin{abstract}
Attitudes towards target language (TL) speakers present an aspect pertaining to the cultural dimension of learning a foreign language. Consequently, the main goals of the study were to determine the participants' attitudes towards the British and Americans, and the degree of social distance the participants felt towards these groups by comparing evaluations of their willingness to identify with TL and L1 speakers. The participants included in the study $(\mathrm{N}=239)$ represented two age groups (secondary and tertiary students), and two educational profiles: philological (Phil) and non-philological (Non-Phil) groups. The main research instruments were an adapted Bogardus Social Distance Scale, which showed good internal consistency on all the subscales, and an English language contact scale, whose aim was to test the participants' actual interaction with the target language speakers (the length of stay in a TL community, potential mobility via school/university exchange programmes). The main finding suggests that Phil groups, being more familiar with the TL culture, evaluated its speakers much more positively and were generally more willing to identify with TL members, even at the most intimate level (spouse). Accordingly, the practical implications would be to encourage foreign language teachers to keep acquainting learners with different cultural elements and work towards fostering positive attitudes to the TL and its culture. What our study has failed to determine, though, is whether the actual contact with real, flesh-and-blood people in contrast to indirect contact with 'imaginary TL speakers' that are the product of one's perception makes a difference in attitudes.
\end{abstract}

Keywords: attitudes to TL speakers, Bogardus Social Distance Scale (BSDS), English as a foreign language (EFL), philological (Phil) and non-philological (Non-Phil) groups, social distance, TL culture and speakers 


\section{Introduction}

"[i]t would be nice if we are studying the language to know a bit more about the country and what people are like there" (Jones 2000, 158)

Learning a second/foreign language (L2) appears to hold a special place in school education (Dörnyei 1994; Ellis 1990; Gardner 2007; Grubor 2015, 2021a). What it has in common with other school subjects is the cognitive dimension, which may be typified by their aptitude, memory capacity, type of intelligence (cf. Gardner's Multiple Intelligences Model) etc. It also shares with the other subjects the affective dimension, which may be associated with how learners feel in or about English classes, learning that language and the like. It may also involve the social dimension through forming specific communities of practice $(\mathrm{CoP})$ that may be constructed in classes, in-school, or out-of-school, consequently joining learners in specific social groups (e.g. chemistry group, maths group, L2 group etc). These groups can be both formal (e.g. school projects, class engagement, extra-curricular activities), and informal (e.g. a group of 'think-alikes'). What makes L2 learning and L2 classes different from all other subjects is the cultural dimension. Second language acquisition does involve the target language (TL) indeed, but also target speakers and their culture(s) that is/are manifested through the language. The former relates to acquiring the language system (pronunciation, grammar, lexis, functional language, discourse), and language skills (Scrivener 2015), and the latter to TL lifestyle(s), attitudes, foods, folklores (Kramsch and Zhu Hua 2016), their mentality, customs, literary and artistic works, which are all the product of historical, geographical, social and political circumstances that may have influenced the way TL speakers are (like).

Culture may be seen as "membership in a discourse community that shares a common social space and history, and common imaginings" (Kramsch 2001, 10 ), or within intercultural studies as the knowledge, motivation, and skills needed to interact successfully with members of different cultural backgrounds (Byram 1997). The importance of this dimension is recognised by scholars, practitioners and leading ELT publishers. Since cultural sensitivity is crucial for language acquisition (Pérez-Vidal 2017), many English textbooks include 'culture corners' (i.e. historical, social, literary content, popular culture etc). Furthermore, they provide audio materials with a wide range of speakers and accents, contents with a large array of customs, geographical locations, and many other culture-specific qualities, all with the aim of bringing TL speakers with all their cultural 'possessions' (language inclusive) closer to L2 learners.

According to Edward T. Hall (1981), there are surface or conscious cultural elements to consider (e.g. food, language, customs) and deep or unconscious 
ones (sets of beliefs, values, perceptions). Acknowledging the possibility of the existence of an endless list of 'cultural' factors that may be relevant to second language acquisition (SLA) or foreign language learning (FLL), our focus will be on the latter (i.e. the participants' beliefs and values manifested through their attitudes to TL speakers). The reason behind this lies in the fact that these may influence L2 students' attitudes to every individual factor relating to L2, on the one hand, and other complex factors, such as attitudes to the L2 itself and/ or learning it, on the other. More precisely, students form attitudes towards L2 speakers and they may project them onto the L2 itself because they are exposed to the L2 and cultural contents closely related to its speakers.

Bearing in mind the fact that English and Serbian cultures differ significantly, we may assume that learners compare their culture (Self) with that of L2 (Other, or more specifically, culturally foreign Other). Accordingly, our main research question is to determine the extent to which the participants are ready to identify with the TL speakers, the British and Americans in specific.

\section{Social Distance and SLA}

Since we set out to explore how Serbian L1 speakers evaluate their own L1 culture through their speakers, members of the L1 language community, and L2 culture through evaluating TL speakers, including the two most widely spread L1 varieties of English, we need to introduce the main theoretical concept, namely social distance. The social distance concept typically reflects "the affective and cognitive proximity of two cultures which come into contact within an individual" (Brown 2014, 188). In general, there are two main reasons why researchers may set to investigate social distance in terms of SLA or FLL. On the one hand, there are authors who maintain that L2 learners may not develop an affinity for TL speakers, in which case the learners develop both social and psychological distance (Gass and Selinker 2008). On the other hand, it is a common belief in sociolinguistic circles that when speakers evaluate a language, they evaluate their speakers at the same time (Bugarski 2003; Edwards 1982), and the other way round. When the L1-L2 contact is of a direct type, as is in the context of bilingualism, the connection is likely to be straightforward, since L2 or 2L1 speakers establish immediate contact with real, flesh and blood people. ${ }^{1}$ In support of this idea, different models and theoretical frameworks based on the idea that L1 speakers compare their culture with L2 culture have been devised in the SLA

${ }^{1}$ In bilingual studies, a difference is made between L2 and 2L1 speakers, whereby the former refers to "sequential bilinguals/second language [speakers] (L2)", whereas the latter denotes "simultaneous bilinguals from birth" (Scherger 2019, 96), i.e. individuals acquiring two languages of equal status in parallel.

Етноантрополошки проблеми, н.с. год. 16 св. 4 (2021) 
context (cf. below). This may not be the case with FLL, where the contact is typically and/or predominantly indirect. This contact being established on an abstract plane, what learners most likely have in mind is 'imaginary' TL speakers, with the formed images being shaped by the learner's perception. Consequently, the product of different types of interaction that learners develop with TL and its culture can be arranged on a continuum with distance and integration at the two opposite ends.

In the context of SLA, the theoretical models based on the social distance concept were developed in the 1980s. One of them is the acculturation model, which assumes that the learning difficulty becomes greater if the distance is larger (Schumann 1978, 1986). In other words, "factors governing the social distance between the L2 learner and the target language community influenced the likelihood of the learner acculturating (i.e. becoming a member of the target-language community)" (Ellis 2015, 30). Therefore, distance reflects the dissimilarity between cultures, and constitutes an impediment to language learning, while integration may lead to group assimilation, acculturation or preservation. Since it is not feasible to measure actual social distance, some authors put forward the idea of perceived social distance (Acton 1979). In essence, the actual dissimilarity between cultures is irrelevant since students' reality is based on their subjective interpretations of it, and hence is not necessarily true. Differently put, their acculturation is dependent on the way they perceive their own culture in relation to the TL culture, and contrariwise. According to this model, learners need to keep optimal distance, which is not at either end of the continuum. Another model is Brown's optimal distance model of SLA (1980), which presupposes that language learning is not only biologically and developmentally determined, but also socioculturally. Brown contends that learners have an optimal chance to become fluent L2 users when the interaction between language and culture reaches an optimal level. This (optimal) level of acculturation (i.e. culture stress) provides the optimal cognitive-affective tension, which consequently exerts the necessary pressure to acquire the L2. Finally, the socio-educational model, a broader model of second language acquisition, assumes the integrativeness concept, or L2 learner's willingness to identify with members of the target language group (Gardner 1985). This model focuses on classroom settings and aspires to connect the social and psychological dimension of L2 learning, assuming that apart from learning a language learners acquire "symbolic elements of a different ethnolinguistic community" (Gardner 1979, 193). The main critique of these two most influential models, Schumann's and Gardner's, is that they are deterministic in that that " $[t]$ here is no allowance for the possibility that learners can themselves influence their social/cultural milieu" (Ellis 2015, 228).

In later research, acculturation, integration, and/or social distance have also been regarded as relevant to SLA, either explicitly or implicitly. Kramsch 
(2001) advocates the idea that language learners develop a desire to behave and think like members of TL groups so that they can eventually be appreciated and accepted by these groups. Yashima and Zenuk-Nishida $(2008,569)$ exploit the international posture concept, formulated as "students' interest in participating in an imagined international community", as an alternative to Gardner's integrativeness, but focusing on international communication rather than communication with a specific TL group. Although the idea behind this concept includes other speakers of English and not necessarily native speakers of TL, imagined TL communities can also be at work in this place. In a word, English speakers may develop an L2 identity in line with how they perceive the L2 culture and its speakers. In the context of staying or living abroad, studies within the language socialisation paradigm are concerned with delineating how learners are socialised to become competent TL culture members through language use, and how they are socialised to use TL (He 2011).

Finally, since the social distance concept is connected with affective variables (Gass and Selinker 2008), many authors employed the attitudes to target language speakers variable to measure the cultural element of SLA (e.g. Dörnyei, Csizér and Németh 2006; Gardner 2007; Grubor 2012 etc). For example, the ECPS model of L2 attitude formation assumes the cultural dimension (besides educational, personality and social), more specifically, a variable influencing L2 learners' attitudes to L2 learning, which may be measured through attitudes to TL speakers (Grubor 2018a). ${ }^{2}$ Since the L2 attitude construct subsumes "systems of various beliefs of an individual, their affective responses and behavioural intentions to perform certain behaviour" (Grubor 2020, 33), its formation is hypothesised to be influenced by the way L2 learners perceive the TL culture and its speakers, among many things. In addition, there are attitudinal scales that include the social distance concept (e.g. the EFLS-ALE scale, which measures attitudes to learning English as a foreign language, includes the nationalism/liberalism factor concerning the influence of English culture on the Serbian language) (cf. Grubor 2012).

Accordingly, to assess the participants' attitudes to English language speakers (ELSs) we employed a modified version of a Bogardus Social Distance Scale (Bogardus 1925; 1933) herein. Despite being 'very old', it is the most widely used scale because "it has a consistent history of use as a measure of interpersonal/intergroup perception over 85 years" (Maurer 2013, 2). In support of this, the entry 'Bogardus scale' generates 210.000 results in the Google search engine, and 24.400 in Google scholars. ${ }^{3}$ In sum, this testing scale meas-

2 The ECPS model of attitude formation was briefly addressed in Grubor (2018a) and will be thoroughly elaborated elsewhere.

3 The search was conducted on 12 June 2021. 
ures people's willingness to engage in different types of social contact with different groups, with varying degrees of intimacy, as well as their readiness to identify with these groups' members (Maurer 2013; Vuksanović 2004; Wark and Galliher 2007). Consequently, the general attitude to the two mentioned speech communities (the British and Americans) was measured through various manifestations of the attitude expressed with regard to the interaction levels (Grubor, Hinić and Petrović-Desnica 2011).

In a nutshell, since attitudes towards the speakers of the TL potentially present a dimension pertaining to the 'cultural element in SLA', the main goals of this study are to determine the participants' attitudes towards the British and Americans, regardless of whether these communities are viewed as actual, 'flesh-and-blood' people or imaginary speakers, the product of the participants' perception, and to test to what extent the evaluation of these TL groups differs from the evaluation of L1 speakers.

\section{Methodology}

The current research included secondary school and university population in Serbia for at least two reasons. It is reasonable to assume that these populations are exposed to the English language and its speakers, both in their formal education and everyday life, and are able to discern the characteristics of different social groups and verbally express them, as well as their attitudes, via self-report.

\section{The Sample}

Initially, 250 participants took part in the research, but the responses of 11 participants were excluded due to incomplete submissions. The final sample thus involved 239 participants, aged 16 to $25(\mathrm{M}=18.66$, $\mathrm{Std}=2.02)$, of both sexes $(\mathrm{m}=74, \mathrm{f}=165)$ and included two age groups: (1) secondary school students $(\mathrm{N}=122)$, aged 16 to 19 , and (2) university students $(\mathrm{N}=117)$, aged 20 to 25. In order to include the participants with different levels of motivation for learning English, we recruited two educational profiles: those having English as their major, i.e. philological group (Phil), and those who had English as one of many school subjects/university courses, i.e. non-philological (NonPhil). Overall, the sample included: (1) secondary school students, at intermediate, upper-intermediate and pre-intermediate levels, attending (1a) philological $(\mathrm{N}=60 ; \mathrm{m}=8, \mathrm{f}=52)$, and ( $1 \mathrm{~b})$ general course $(\mathrm{N}=62 ; \mathrm{m}=32, \mathrm{f}=30)$, and (2) university students, at proficiency and upper-intermediate levels, attending (2a) English language studies $(\mathrm{N}=53 ; \mathrm{m}=15, \mathrm{f}=38)$ and $(2 \mathrm{~b})$ Economics $(\mathrm{N}=64$; $\mathrm{m}=19 ; \mathrm{f}=45)$. 


\section{Instruments and Procedures}

To determine the participants' background information, we used the following instruments:

(1) a brief sociodemographic questionnaire to gain some general data (age, sex, educational profile),

(2) an English language contact scale, a self-rating scale, to obtain some basic information on the participants' actual interaction with the target language speakers (if they have stayed in TL countries, how long, how often they establish interaction with TL speakers), as well as their potential mobility. ${ }^{4}$

To assess the participants' attitudes to English language speakers (ELSs), we employed a Bogardus Social Distance Scale. The scale was not used in its original, unabridged form. We made some adjustments in line with the context and subject matter of our study. The original scale subsumes seven interaction levels, but the most extreme negative scenario (to have them exiled from the participants' country) was excluded from the current study, as being inappropriate for the setting in which the research was conducted. Thus, we included six levels of social interaction (i.e. intimacy), ranging from the least to the most intimate (e.g. how willing they are to have them as tourists in their country or to enter into marriage with them). Furthermore, we did not use the original two-dimensional scale format (yes-no), but rather a modified five-point Likert-type scale so as to determine subtle differences in scores. The values ranged from 1 I would mind it a lot to 5 I wouldn't mind it at all to make the specified type of contact with the stated speech communities. In order to test potential differences in attitudes towards L1 and L2 speakers, the speech communities included were the British and Americans (as the two most widely spread varieties of English, typically learnt at Serbian schools), and Serbians (as members of their own nation). Lastly, one more adjustment was made in line with the age of our participants; namely, 'work colleague' was changed into 'school/university mate'.

Since the assumed levels of intimacy offered in the original scale may not necessarily match our participants' opinions, we had relied on the pilot study conducted by Grubor (2012), since the sample included the same populations. As reported by Grubor (2012), 70 participants sharing the important characteristics of the target population of our study (the same age and educational profile groups) had been tested to establish these groups' standards of intimacy, as was the case with other studies (e.g. Thyne and Lawson 2001). To put it differently, the pilot participants had been given a task to rank the given levels of interaction

4 The grammar school included in the study had an exchange programme with Brno, Czech Republic, and the university was involved in different mobility programmes with different European countries.

Етноантрополошки проблеми, н.с. год. 16 св. 4 (2021) 
from the least to the most intimate, and the mean score of the responses served as the reference point for the interpretation of the data gathered on the scale. Therefore, the data were taken as valid for the target sample since the testing of the participants from our sample might have influenced their responses otherwise. The main findings from this pilot study had revealed that secondary school students made a difference between the levels 'boyfriend/girlfriend', which was intentionally devised for this sample in accordance with their age, and 'husband/ wife'. Since this was not the case with tertiary students, we also excluded the former and left the latter level in the current study to balance the intimacy level in both age groups. Similarly, upon calculating the mean scores of each level, the intimacy level order was established accordingly. The rankings were very similar in secondary school and university students' responses. In specific, the least intimate level according to the pilot sample was reported to be 1 - tourists, followed by 2 - citizens, 3 - neighbours, 4 - school/university mates, and finally the most intimate 5 - good friends and 6 - spouses (husbands/wives). To conclude, the only difference in comparison with the original scale order was to do with neighbours and school/university mates. Nonetheless, the mean scores on the said levels were quite similar in our participants as well.

Finally, the given instructions were taken from the original scale, reading the following guidelines: remember to report your first reactions; your reactions should be reactions to every nation as a group; do not take the best or worst member of the group that you know as a true measure, but think of an overall, typical picture of the entire group. In addition to being instructed to evaluate the TL groups as a whole, through instant responses of their impressions, they were also required to express the degree of willingness to identify with these groups' members on differing levels of intimacy.

\section{Statistical Analyses}

To analyse the gathered data, we performed the following statistical analyses within the statistical programme IBM SPSS Statistics 21: descriptive statistics (percentage, means, standard deviation, standard error), one-way ANOVA, paired-samples T test, correlation analysis (Pearson correlation coefficient, r), a scale reliability test (Cronbach's alpha, $\alpha$ ), effect size (eta squared, $\eta^{2}$ ).

\section{Results}

\section{Attitudes to English Language Speakers}

Prior to presenting the results on the Bogardus Social Distance Scale (BSDS), within the age and educational profile groups, we will first present the scale reli- 
ability test. Cronbach's alpha showed high scores on the entire sample $(\alpha=.880)$, as well as on the subscales (Br: $\alpha=.780$; Am: $\alpha=.839$; Ser: $\alpha=.825$ ), which supports good internal consistency of the scale employed in this study.

Overall attitudes towards TL speakers were positive in the entire sample $(\mathrm{M}=25.97 ; \mathrm{SD}=3.52 ; \mathrm{SE}=0.23)$. With respect to the participants' scores, descriptive statistics shows that all subgroups held positive attitudes towards all the tested nations. What can be noticed from the values of standard deviation is that the participants' responses were quite stable, with the scores on the American subscale being somewhat spread and not clustered. Mean scores are given in Table 1.

Table 1 Attitudes to Br, Am and Ser: Descriptive statistics

\begin{tabular}{|c|c|c|c|c|c|}
\hline \multicolumn{2}{|c|}{$\begin{array}{l}\text { Social Distance } \\
\text { Scale }\end{array}$} & \multirow{2}{*}{$\begin{array}{c}\begin{array}{c}\text { Philological } \\
\text { Course }\end{array} \\
28.10\end{array}$} & \multirow{2}{*}{$\begin{array}{c}\text { General Course } \\
25.23\end{array}$} & \multirow{2}{*}{$\begin{array}{c}\begin{array}{c}\text { Faculty of } \\
\text { Philology }\end{array} \\
27.25\end{array}$} & \multirow{2}{*}{$\begin{array}{c}\begin{array}{c}\text { Faculty of } \\
\text { Economics }\end{array} \\
25.77\end{array}$} \\
\hline \multirow{3}{*}{ M } & $\mathrm{Br}$ & & & & \\
\hline & Am & 27.07 & 24.03 & 26.38 & 25.00 \\
\hline & Ser & 29.13 & 28.63 & 28.42 & 28.72 \\
\hline \multirow{3}{*}{ SD } & $\mathrm{Br}$ & 2.78 & 3.61 & 2.24 & 3.17 \\
\hline & Am & 4.07 & 4.48 & 3.58 & 3.83 \\
\hline & Ser & 1.91 & 2.98 & 2.37 & 1.86 \\
\hline \multirow{3}{*}{ SE } & $\mathrm{Br}$ & 0.39 & 0.46 & 0.31 & 0.40 \\
\hline & Am & 0.53 & 0.57 & 0.49 & 0.48 \\
\hline & Ser & 0.25 & 0.38 & 0.33 & 0.23 \\
\hline \multirow{3}{*}{ Min } & $\mathrm{Br}$ & 18 & 11 & 22 & 18 \\
\hline & Am & 12 & 10 & 16 & 9 \\
\hline & Ser & 22 & 13 & 21 & 24 \\
\hline \multirow{3}{*}{ Max } & $\mathrm{Br}$ & 30 & 30 & 30 & 30 \\
\hline & Am & 30 & 30 & 30 & 30 \\
\hline & Ser & 30 & 30 & 30 & 30 \\
\hline \multirow{5}{*}{$\begin{array}{l}T L \\
\text { total } \\
(\max 30)\end{array}$} & $\mathrm{M}$ & 27.58 & 24.32 & 26.81 & 25.38 \\
\hline & SD & 3.07 & 3.89 & 2.76 & 3.32 \\
\hline & SE & 0.40 & 0.49 & 0.38 & 0.41 \\
\hline & Min & 19 & 11 & 19.50 & 17.00 \\
\hline & Max & 30 & 30 & 30 & 30 \\
\hline
\end{tabular}

Br: the British, Am: Americans, Ser: Serbians

An ANOVA test showed significant differences between groups on the subscales of the British $\left(\mathrm{F}(3,235)=11.569 ; \mathrm{p}=.000 ; \eta^{2}=.13\right)$, Americans $(\mathrm{F}(3$, $\left.235)=6.994 ; p=.000 ; \eta^{2}=.08\right)$, but not Serbians. ${ }^{5}$ In order to check where the differences lie, we performed a Tukey's post hoc test, which showed a significant difference between the students attending philological (PC) and general course (GC) $(\mathrm{MD}=2.874$;

5 Eta squared range: small .01, medium .06, large effect size .14 (Dörnyei 2011; Larson-Hall 2010). 
$\mathrm{p}=.000), \mathrm{PC}$ and students of Economics ( $\mathrm{FE})(\mathrm{MD}=2.334 ; \mathrm{p}=.000)$, as well as the English language studies students (FP) and GC (MD=2.019; $\mathrm{p}=.002)$. To conclude, a difference was found between Phil and Non-Phil groups in secondary school students but not in university students.

In order to establish whether specific subgroups evaluated members of their nation better than English language speakers, we performed paired-samples $T$ tests within each individual group (cf. Table 2). As illustrated in the table, although a difference was found between the British and Serbians, and Americans and Serbians in all the subgroups, the difference was again much smaller in Phil groups.

Table 2 Attitudes to $\mathrm{Br}$, Am and Ser: Within-group comparisons

\begin{tabular}{|c|c|c|c|c|c|}
\hline \multirow{4}{*}{$\begin{array}{l}\text { Educational profile } \\
\text { Philological Course } \\
\text { (PC) }\end{array}$} & \multicolumn{2}{|c|}{$\begin{array}{l}\text { (I) Factor } 1(\mathrm{~J}) \\
\text { Factor I }\end{array}$} & $\mathrm{t}$ & $\mathrm{df}$ & \multirow{2}{*}{$\frac{\mathrm{p}}{.018}$} \\
\hline & $\mathrm{Br}$ & $\mathrm{Am}$ & 2.442 & 59 & \\
\hline & $\mathrm{Br}$ & Ser & -2.707 & 59 & .009 \\
\hline & Am & Ser & -3.784 & 59 & .000 \\
\hline \multirow[t]{3}{*}{ General Course (GC) } & $\mathrm{Br}$ & $\mathrm{Am}$ & 2.920 & 61 & .005 \\
\hline & $\mathrm{Br}$ & Ser & -5.620 & 61 & .000 \\
\hline & Am & Ser & -7.160 & 61 & .000 \\
\hline \multirow{3}{*}{$\begin{array}{l}\text { Faculty of Philology } \\
\text { (FP) }\end{array}$} & $\mathrm{Br}$ & $\mathrm{Am}$ & 2.742 & 52 & .008 \\
\hline & $\mathrm{Br}$ & Ser & -4.037 & 52 & .000 \\
\hline & Am & Ser & -5.819 & 52 & .000 \\
\hline \multirow{3}{*}{$\begin{array}{l}\text { Faculty of Economics } \\
\text { (FE) }\end{array}$} & $\mathrm{Br}$ & $\mathrm{Am}$ & 2.662 & 63 & .010 \\
\hline & $\mathrm{Br}$ & Ser & -8.264 & 63 & .000 \\
\hline & Am & Ser & -8.262 & 63 & .000 \\
\hline
\end{tabular}

Factor 1: Nation

In terms of the individual levels of the BSDS, the entire sample most positively evaluated social contacts with the Serbians (i.e. their nation), then with the British, and finally with the Americans (cf. Table 3).

Table 3 Mean scores on the BSDS: Social contact levels

Social contact

levels

Nation

\begin{tabular}{l|ccc|ccc|ccc}
\multicolumn{1}{c}{} & M & Min & Max & M & Min & Max & M & Min & Max \\
\hline HUSBANDS/WIVES & 3.73 & 1 & 5 & 3.53 & 1 & 5 & 4.76 & 3 & 5 \\
GOOD FRIENDS & 4.49 & 1 & 5 & 4.34 & 1 & 5 & 4.87 & 3 & 5 \\
NEIGHBOURS & 4.41 & 1 & 5 & 4.23 & 1 & 5 & 4.71 & 2 & 5 \\
SCHOOL/UNIVERSITY & 4.49 & 1 & 5 & 4.37 & 1 & 5 & 4.80 & 2 & 5 \\
MATES & & & & & & & & & \\
CITIZENS & 4.54 & 1 & 5 & 4.45 & 1 & 5 & 4.82 & 1 & 5 \\
TOURISTS & 4.81 & 1 & 5 & 4.60 & 1 & 5 & 4.79 & 1 & 5 \\
\hline
\end{tabular}

An ANOVA test detected statistically significant differences between the subgroups on the individual levels of social contact (interaction), the most significant being on the spouse level (husband/wives), and the least on the tour- 
ist level, which corresponds with the results obtained in the said pilot study (cf. Table 4). Nevertheless, a difference of large effect size was only detected on the most intimate level, the spouse level, whereas all other differences were of medium effect size (cf. Table 4). A Tukey's post hoc test confirmed that Phil secondary school participants evaluated the members of both groups (the British, Americans) much more positively than the Non-Phil group on the spouse level $(\mathrm{Br}: \mathrm{MD}=0.917 ; \mathrm{p}=.000 ; \mathrm{Am}$ : $\mathrm{MD}=0.985 ; \mathrm{p}=.000$ ), which was not the case with university students. The differences between educational profiles within the secondary students were also detected on all other individual levels of the BSDS, except for the tourist level in terms of the Americans. However, the MD values indicate that these differences were not so large (good friends $\mathrm{Br}: \mathrm{MD}=0.470, \mathrm{p}=.002, \mathrm{Am}: \mathrm{MD}=0.555, \mathrm{p}=.004$; neighbours $\mathrm{Br}: \mathrm{MD}=0.520, \mathrm{p}=.005, \mathrm{Am}: \mathrm{MD}=0.552, \mathrm{p}=.021$; school/university mates $\mathrm{Br}$ : $\mathrm{MD}=0.539, \mathrm{p}=.001, \mathrm{Am}: \mathrm{MD}=0.536, \mathrm{p}=.008$; citizens $\mathrm{Br}: \mathrm{MD}=0.297, \mathrm{p}=.009$, $\mathrm{Am}: \mathrm{MD}=0.414, \mathrm{p}=.044$; tourists $\mathrm{Br}: \mathrm{MD}=0.470, \mathrm{p}=.002$, $\mathrm{Am}: \mathrm{MD}=0.555$, $\mathrm{p}=.004)$

Table 4 Between-group differences on the BSDS:

Social contact levels

Social contact levels

Nation

\begin{tabular}{l|ccc|ccc} 
& \multicolumn{3}{c}{$\mathrm{Br}$} & \multicolumn{4}{c}{ Am } \\
& $\mathrm{F}(3,218)$ & $\mathrm{p}$ & $\eta^{2}$ & $\mathrm{~F}(3,218)$ & $\mathrm{p}$ & $\eta^{2}$ \\
\hline HUSBANDS/WIVES & 8.956 & .000 & .11 & 9.262 & .000 & .11 \\
GOOD FRIENDS & 4.910 & .003 & .06 & 5.328 & .001 & .07 \\
NEIGHBOURS & 4.983 & .002 & .06 & 3.809 & .011 & .05 \\
SCHOOL/UNIVERSITY MATES & 5.966 & .001 & .07 & 4.021 & .008 & .05 \\
CITIZENS & 5.501 & .001 & .07 & 4.777 & .003 & .06 \\
TOURISTS & 3.650 & .013 & .05 & 2.827 & .039 & .04 \\
\hline
\end{tabular}

Finally, concerning the within-group comparisons, paired-samples $\mathrm{T}$ tests show similar results as with the overall attitude results. All the subgroups made a difference between their nation and both target nations, most prominently on the most intimate level (spouse), although the difference in Non-Phil groups was at least twice as big as it was in Phil. Overall, the participants seemed to evaluate the British more positively than Americans. In addition, the secondary school students did not make a difference between having a British or an American as a spouse, as university students did. Both Phil groups did not make a difference between having either TL nation as their good friends, as Non-Phil did. As for the last two levels, those of citizens and tourists, for obvious reasons we excluded the comparisons between the TL nations and L1 nation. With regard to these two, when the sample made any difference, it was in favour of the British. 
Table 5 Within-group differences on the BSDS: Social contact levels

\begin{tabular}{|c|c|c|c|c|c|c|c|c|c|c|}
\hline \multirow{2}{*}{ Level } & \multirow{2}{*}{\multicolumn{2}{|c|}{ Pairs }} & \multicolumn{2}{|c|}{$P C(d f=59)$} & \multicolumn{2}{|c|}{$\mathrm{GC}(\mathrm{df}=61)$} & \multicolumn{2}{|c|}{$\mathrm{FP}(\mathrm{df}=52)$} & \multicolumn{2}{|c|}{$\mathrm{FE}(\mathrm{df}=63)$} \\
\hline & & & $\mathrm{t}$ & $\mathrm{p}$ & $\mathrm{t}$ & $\mathrm{p}$ & $\mathrm{t}$ & $\mathrm{p}$ & $\mathrm{t}$ & $\mathrm{p}$ \\
\hline \multirow{3}{*}{ SPOUSE } & $\mathrm{Br}$ & $\mathrm{Am}$ & 1 & 1 & 1 & 1 & 2.033 & .047 & 2.959 & .004 \\
\hline & $\mathrm{Br}$ & Ser & -3.756 & .000 & -9.342 & .000 & -4.276 & .000 & -8.828 & .000 \\
\hline & $\mathrm{Am}$ & Ser & -4.389 & .000 & -10.474 & .000 & -5.163 & .000 & -10.479 & .000 \\
\hline \multirow{4}{*}{$\begin{array}{l}\text { GOOD } \\
\text { FRIEND }\end{array}$} & & & \multicolumn{2}{|c|}{$\mathrm{PC}(\mathrm{df}=55)$} & \multicolumn{2}{|c|}{$\mathrm{GC}(\mathrm{df}=54)$} & \multicolumn{2}{|c|}{$\mathrm{FP}(\mathrm{df}=48)$} & \multicolumn{2}{|c|}{$\mathrm{FE}(\mathrm{df}=59)$} \\
\hline & $\mathrm{Br}$ & Am & 1 & 1 & 2.189 & .033 & 1 & 1 & 2.688 & .009 \\
\hline & $\mathrm{Br}$ & Ser & 1 & 1 & -4.279 & .000 & -3.474 & .001 & -5.167 & .000 \\
\hline & $\mathrm{Am}$ & Ser & -2.592 & .012 & -5.775 & .000 & -3.358 & .002 & -5.854 & .000 \\
\hline \multirow{4}{*}{ NEIGHBOUR } & & & \multicolumn{2}{|c|}{$\mathrm{PC}(\mathrm{df}=55)$} & \multicolumn{2}{|c|}{$\mathrm{GC}(\mathrm{df}=54)$} & \multicolumn{2}{|c|}{$\mathrm{FP}(\mathrm{df}=48)$} & \multicolumn{2}{|c|}{$\mathrm{FE}(\mathrm{df}=59)$} \\
\hline & $\mathrm{Br}$ & $\mathrm{Am}$ & 2.569 & .013 & 2.355 & .022 & 1 & 1 & 1 & 1 \\
\hline & $\mathrm{Br}$ & Ser & -2.187 & .033 & -2.816 & .007 & 1 & 1 & -3.452 & .001 \\
\hline & Am & Ser & -3.305 & .002 & -4.709 & .000 & -2.678 & .010 & -4.288 & .000 \\
\hline \multirow{4}{*}{$\begin{array}{l}\text { SCHOOL/ } \\
\text { UNIVERSITY } \\
\text { MATE }\end{array}$} & & & \multicolumn{2}{|c|}{$\mathrm{PC}(\mathrm{df}=55)$} & \multicolumn{2}{|c|}{$\mathrm{GC}(\mathrm{df}=54)$} & \multicolumn{2}{|c|}{$\mathrm{FP}(\mathrm{df}=48)$} & \multicolumn{2}{|c|}{$\mathrm{FE}(\mathrm{df}=59)$} \\
\hline & $\mathrm{Br}$ & Am & 1 & 1 & 1 & 1 & 1 & 1 & 1 & 1 \\
\hline & $\mathrm{Br}$ & Ser & -2.204 & .032 & -4.869 & .000 & 1 & 1 & -4.284 & .000 \\
\hline & $\mathrm{Am}$ & Ser & -2.814 & .007 & -4.997 & .000 & -2.274 & .027 & -4.296 & .000 \\
\hline \multirow{2}{*}{ CITIZEN } & & & \multicolumn{2}{|c|}{$\mathrm{PC}(\mathrm{df}=55)$} & \multicolumn{2}{|c|}{$\mathrm{GC}(\mathrm{df}=54)$} & \multicolumn{2}{|c|}{$\mathrm{FP}(\mathrm{df}=48)$} & \multicolumn{2}{|c|}{$\mathrm{FE}(\mathrm{df}=59)$} \\
\hline & $\mathrm{Br}$ & $\mathrm{Am}$ & 2.017 & .049 & 1 & 1 & 1 & 1 & 1 & 1 \\
\hline \multirow{2}{*}{ TOURIST } & & & \multicolumn{2}{|c|}{$\mathrm{PC}(\mathrm{df}=55)$} & \multicolumn{2}{|c|}{$\mathrm{GC}(\mathrm{df}=54)$} & \multicolumn{2}{|c|}{$\mathrm{FP}(\mathrm{df}=48)$} & \multicolumn{2}{|c|}{$\mathrm{FE}(\mathrm{df}=59)$} \\
\hline & $\mathrm{Br}$ & Am & 2.192 & .033 & 2.751 & .008 & 2.294 & .026 & 1 & 1 \\
\hline
\end{tabular}

PC (Philological Course), GC (General Course), FP (Faculty of Philology), FE (Faculty of Economics);/: no significant differences

\section{English Language Contact Background}

Since the participants' attitudes may well be influenced by the fact whether they establish any kind of contact with TL speakers, we performed a correlation analysis. No significant correlations were found between their general attitude to TL speakers and the number and/or length of stay in TL countries, nor how frequently they conversed with TL speakers or chatted with them online. However, this connection should not be discarded completely since the portion of the sample meeting these criteria was negligible. In sum, our participants did not come into contact with TL speakers in an amount sufficient to make any comparisons and draw any relevant conclusions, therefore there is room to further investigate this connection in some future studies. Finally, the number of students included in any mobility programme was also negligible, which is why we may assume that the international posture variable may not be at work in this sample. 


\section{Discussion}

Since attitudes to TL speakers are likely to influence the formation of L2 attitudes in general, we set out to explore secondary and tertiary students' attitudes to TL speakers. To this end, we have chosen the two most widely spread English varieties, and more importantly, those that are most typically, if not the only ones studied in the formal education in Serbia. In addition, we aimed at investigating the level of social and psychological distance that the participants experience with these two nations, which may be relevant both to the investigation into sociocultural, affective variables within broader models of SLA, but also cultural studies. In the context of the former, the mentioned empirical study (Grubor 2012) found that attitudes towards TL speakers was one of the variables to explain the attitude to learning English as a foreign language, which in turn influenced achievement through the agency of intention to master the English language.

In the current research, the participants showed positive attitudes towards the TL speakers included in this study, the British and Americans. In general, Phil groups evaluated the TL speakers much more positively than Non-Phil groups. The differences between the evaluation of their own speakers and TL speakers (the social distance) were found in all the subgroups of the sample, but they were smaller in Phil groups, even at the most intimate level (spouse). It follows therefore that Phil groups were more willing to come into contact and identify with the nations in question, even at the most intimate level. We may assume that the Phil participants are familiar with the TL culture to a much greater extent than Non-Phil groups, and thus evaluate these nations better and make a smaller difference between their own and TL culture. With this in view, previous research found that higher proficiency students, which in our case could be Phil groups, have a higher level of intercultural awareness and that this awareness develops with pre-training (Hismanoglu 2011). Against this backdrop, Phil groups study literary TL works, as part of their curriculum, they have cultural studies courses at the university level, and at the secondary level, these elements are either closely intertwined with other class contents or they have separate lessons aimed at these aspects. ${ }^{6}$

In terms of the two L2 nations, overall, Americans were the least positively evaluated nation by our sample, as regards both the general attitude and individual levels of intimacy tested by the scale. In secondary school students, Phil

${ }^{6}$ Both Phil and Non-Phil secondary school students are exposed to different samples of language (written or oral) that include different cultural elements (e.g. music, food, customs etc). However, specific cultural elements are on the Phil group curriculum, such as the analysis of authentic literary works of English/American writers (as part of reading assignments). 
groups more positively evaluated both TL nations than Non-Phil groups, both in the general attitude and on the individual levels of the scale. Phil groups also made no difference in having TL nations as their good friends in comparison to their nation, as Non-Phil did. Interestingly, the secondary students made no difference between having the British or Americans as a spouse, whereas the tertiary students did, with the British being more 'acceptable' as husbands and wives. This finding is somewhat challenging if we take into account the fact that American English is regarded the most influential and most frequently used variety according to the World System of Englishes model, or the 'hub', 'hypercentral' variety (Mair 2013). However, according to this model British English is regarded as 'super-central' variety, which also makes an impact on other varieties of English. In other words, the influence is assumed to be top-down, from the hypercentral variety (American English) but also from the super-central ones (British English) to the varieties in the lower levels of the layered hierarchy (Seoane 2016, 5). Although we did not test the personal preference and/or choice/ use of the specific variety, nor included 'Serbian English' as a potential variety, one line of thought may be that L2 learners do not evaluate the language through its speakers, as previously presupposed. ${ }^{7}$ However, such a statement would be overtly simplified and the situation becomes even fuzzier and more complicated with the international status of "English as the hypercentral language" (de Swaan 2013, 71), and the fact that both the British and Americans speak this language. On the one hand, American variety seems to be omnipresent in popular culture (music, films, shows etc), thereby most likely wielding enormous influence over young people. On the other hand, speakers' perceptions may be 'faulty', in line with the results of some studies showing that the majority of L2 speakers actually mix the varieties, many even without realising it (cf. Grubor, Bjelogrlić and Hinić 2008; Grubor and Hinić 2011).

Finally, although the sample involved in the current research may be said to represent typical foreign language learners, since they did not stay in TL countries, nor were involved in mobility programmes, the indirect contact they establish with TL culture(s) through different media must not be discarded entirely. Even stay-abroad (SA) research has frequently pointed to the fact that students who stay in TL countries tend to stay within their L1 communities (other students staying abroad) rather than immerging with TL speakers (Mitchell, Tracy-Ventura and McManus 2015), questioning the actual influence of SA on students' integration into TL communities. Against such a backdrop, many authors advocate the idea that the notion of culture must be redefined in times of globalisation. The reason is the fact that "the Internet and networking culture on-line

7 This statement does not hold in the context of different varieties of one's own language (L1), since a plethora of sociolinguistic research speaks in favour of this premise. 
[...] offer an a-historical world of connections and relations that replace quality with quantity, time with space, reality with hyperreality" (Kramsch 2011, 309). It is reasonable to assume, therefore, that these 'external influences' $d o$ shape learners' perceptions of the TL culture, its speakers, language, on the one hand, but also the 'international community' as termed in the literature, on the other. ${ }^{8}$

Finally, we need to point to some of the limitations of the current study. The main limitations are associated with the sample and its nature: it was random, but not representative according to the statistical criteria; there was an uneven distribution of the participants by the sex criterion; the number of the students who stayed in an English-speaking country or were included in a mobility programme was insignificant. Furthermore, the nature of the research instrument may be somewhat limiting: regardless of the 'immediate' nature of the scale items, self-reports do bring a danger of giving socially desirable answers (Grubor 2012, 2021).

\title{
Conclusion
}

\begin{abstract}
"Beneath the clearly perceived, highly explicit surface culture, there lies a whole other world" (Hall 1981, 29)
\end{abstract}

Out of many functions, language serves the purpose of communicating one's ideas, thoughts, desires etc, expressing one's identity, as well as culture (Kirkpatrick 2007). The 'cultural element' of SLA, as we termed it herein, was typified by the participants' attitudes towards TL speakers. These attitudes were measured by instant responses of the participants' impressions of two TL groups. This measure of attitudes thus 'compels' the participants to imagine different scenarios and be as straightforward as possible, leaving less room for contemplation, which may be influenced by social desirability that is frequently associated with self-reports (Grubor 2021).

Although a growing number of studies pinpoint the mobility of people and blending of cultures in a globalised world of modern times (e.g. Butler 2017), or posit the existence of 'cyberculture' (Kramsch and Zhu Hua 2016, 312), thereby "challenging simplistic dichotomies of Self and Other" (Moon 1996, 308), this seems not to be the case with our sample, at least from the formal point of view (if we exclude the impact of global networks, which we did/could not measure). The main finding that this study has revealed suggests that individuals who are

${ }^{8}$ Ethnolinguistic communities that do not belong to the TL community in its 'purest' form, but those using English for a wide range of purposes (e.g. using English for travelling, business, studying, or any kind of mobility purposes). 
more familiar with the TL culture turn out to evaluate its speakers more positively and are generally more willing to identify with TL members. In practical terms, class implications for teachers would be to include more 'cultural' elements in their English classes and work towards fostering positive attitudes to the TL and its culture.

Apart from social distance scales, social distance can also be measured indirectly through specific items on an attitudinal scale, as with the EFLS-ALE scale previously mentioned (Grubor 2020). In the three-factor structure obtained via confirmatory factor analysis, one of the extracted factors was 'language purism' (Grubor 2020), or else 'nationalism/liberalism' (Grubor 2012, 2018b). However, this instance of nationalism/liberalism (language purism) rather reflects "foreign speakers' tolerance to changes coming from other languages on a more abstract level rather than posing an actual threat to their L1. [...] [but] may be indicative of the acceptance of other cultures, their members and cultural forms of expression, and thus a telltale sign of L2 attitudes" (Grubor 2021, 301) .

In a similar vein, we contend that foreign language learners may form beliefs about 'imaginary' communities that are the product of the learner's perception, resulting from their value systems, entrenched beliefs, previous experiences, and the like. As Kramsch and Zhu Hua put it $(2016,318)$, these TL communities may be "a reconstruction of past communities and historically constituted relationships, but also a community of the imagination". ${ }^{9}$ Simply put, the concept of integration may be an actual or metaphorical integration into the L2 community (Csizér and Dörnyei 2005), and if learners' perceptions should be arranged on the distance-integration continuum, an intersection point would not be perfectly stable but rather moveable because their integration is very likely to be a fluid category, dependent on a wide range of factors.

In sum, regardless of the fact whether the social distance is directed at actual flesh and blood people, or else 'imaginary TL speakers', who are the product of L2 learners perceptions and/or 'imaginings', this construct tends to be valid in the context of SLA, as some previous studies suggest (e.g. Grubor 2012). In addition, no matter the context and reality, it is reasonable to assume that perception takes on an added importance. Even in cases of predominantly typical foreign language learners, as was the case with our sample, TL communities do not diminish in importance. Whether actual or imaginary, in the learner's eye, they are the product of their perception, personal interpretation based on dif-

9 Note that 'imaginary communities' discussed herein refer to L2 learners' perceptions and how they imagine TL speakers to be, rather than 'imagined communities' that are used to refer to predominantly international communities in line with the international status of English (Yashima \& Zenuk-Nishida 2008) or 'a desired community that offers possibilities for an enhanced range of identity options in the future" (Kramsch \& Zhu Hua 2016, 318). 
ferent forms of input they receive about them through a wide range of stimuli, or their personal experience with them (direct or indirect). In a word, they may be the result of a stereotypical image, of a 'unique' (personal) image, and/or an entirely personal experience of a culture and/or its speakers.

In terms of future directions that some prospective studies may take, the next possible step could be to empirically test the role of the distance/integration variable within a broader model of L2 attitude formation. What the current study failed to determine is whether there is a difference in attitude between students who have been exposed to real-life TL speakers and those who base their beliefs only on their own 'imaginings', which may thus be investigated in further research.

\section{References}

Acton, William. 1979. "Second language learning and perception of difference in attitude" Unpublished doctoral thesis. University of Michigan.

Bogardus, Emory, Stephen. 1925. "Social Distance and Its Origins". Journal of Applied Sociology 9: 216-226.

Bogardus, Emory, Stephen. 1933. "A Social Distance Scale”. Sociology and Social Research 17: 265-271.

Brown, H. Douglas. 1980. "The Optimal Distance Model of Second Language Acquisition”. TESOL Quarterly 14: 157-164. https://doi.org/10.2307/3586310

Brown, H. Douglas. 2014. Principles of Language Learning and Teaching (6 $6^{\text {th }} \mathrm{ed}$.). New York: Pearson Education, Inc.

Bugarski, Ranko. 2003. Lingvistika o čoveku. Beograd: Prosveta.

Butler, Yuko Goto. 2017. "ISLA in East Asian Contexts". In The Routledge Handbook of Instructed Second Language Acquisition, edited by Shawn Loewen and Masatoshi Sato, 321-337. New York: Taylor \& Francis.

Byram, Michael. 1997. Teaching and Assessing Intercultural Communicative Competence. Clevedon: Multilingual Matters.

Csizér, Kata and Zoltán Dörnyei. 2005. "The internal structure of language learning motivation and its relationship with language choice and learning effort". Modern Language Journal 89(1): 19-36.

De Swaan, Abram. 2013. "Language Systems". In The Handbook of Language and Globalization, edited by Nikolas Coupland, 56-76. Malden MA: Blackwell.

Dörnyei, Zoltan. 1994. "Motivation and Motivating in the Foreign Language Classroom". Modern Language Journal 78 (3): 273-284. https://doi.org/10.1111/j.1540-4781.1994.tb02042.x

Dörnyei, Zoltan. 2011. Research Methods in Applied Linguistics. Oxford: Oxford University Press.

Dörnyei, Zoltan, Kata Csizér and Nora Németh. 2006. Motivation, Language Attitudes and Globalisation: A Hungarian Perspective. Clevedon: Multilingual Matters.

Edwards, John. 1982. "Language Attitudes and their Implications Among English Speakers: Social and Applied Contexts". In Attitudes Towards Language Variation, edited by Ellen B. Ryan and Howard Giles, 20-33. London: Edward Arnold. 
Ellis, Rod. 1990. Instructed Second Language Acquisition. Oxford: Basil Blackwell.

Ellis, Rod. 2015. Understanding Second Language Acquisition (2 ${ }^{\text {nd }}$ ed.). Oxford: Oxford University Press.

Gardner, Robert, Charles. 1979. "Social Psychological Aspects of Second Language Acquisition". In Language and Social Psychology, edited by Howard Giles and Robert St. Clair, 193-220. Oxford: Blackwell.

Gardner, Robert, Charles. 1985. Social Psychology and Second Language Learning: The Role of Attitude and Motivation. London: Edward Arnold.

Gardner, Robert, Charles. 2007. "Motivation and Second Language Acquisition". Porta Linguarium 8: 9-20.

Gass, Susan, M. and Larry Selinker. 2008. Second Language Acquisition: An Introductory Course ( $3^{\text {rd }}$ ed.). New York: Routledge.

Grubor, Jelena. 2012. „Stavovi prema učenju engleskog kao stranog jezika i njihov uticaj na postignuće" Doktorska dis. Filološki fakultet, Univerzitet u Beogradu.

Grubor, Jelena. 2015. „Ispitivanje L2 stavova”. Inovacije u nastavi - časopis za savremenu nastavu 28 (1): 140-148. https://doi.org/10.5937/inovacije1501140G

Grubor, Jelena. 2018a. „Vannastavni input i stav prema učenju engleskog kao stranog jezika“. Primenjena lingvistika 19: 61-74. https://doi.org/10.18485/primling.2018.19.6

Grubor, Jelena. 2018b. „Stavovi roditelja prema učenju engleskog jezika svoje dece”. Nastava i vaspitanje 67 (3): 453-469. https://doi.org/10.5937/nasvas1803453G

Grubor, Jelena. 2020. "What Makes up the Attitude to Learning English: EFLS-ALE Scale”. In Science Beyond Boundaries 3, Vol. 2 Language and Languages, edited by Golub Jašović, Branislava Dilparić and Jelena Bajović, 31-51. Kosovska Mitrovica: Faculty of Philosophy, University of Priština.

Grubor, Jelena. 2021. "L2 Attitudes Across Secondary Education: How (Relatively) Stable Are They?” Nasleđe (Kragujevac) 48: 299-314.

Grubor, Jelena and Darko Hinić. 2011. "Pronunciation Tendencies Towards British and American English in EFL Teachers in Serbia: Are Teachers Immune to Global Influences?" Nasleđe (Kragujevac) 8 (17): 299-310.

Grubor, Jelena, Darko Hinić and Jelena Petrović-Desnica. 2011. "How Do EFL Teachers Feel About Touching Wood or Knocking on Wood? Attitudes and Choice of British/ American English". In ELLSIIR Proceedings, Volume I, edited by Nenad Tomović and Jelena Vujić, 447-456. Belgrade: Faculty of Philology, University of Belgrade.

Grubor, Jelena, Nataša Bjelogrlić and Darko Hinić. 2008. "British or American English in Serbia, or Both?" Nasleđe (Kragujevac) 5 (11): 123-131.

Hall, Edward, Twitchell. 1981. Beyond Culture. New York: Anchor.

He, Agnes Weiyun. 2011. "Language Socialization". In The Routledge Handbook of Applied Linguistics, edited by James Simpson, 287-302. Abingdon: Routledge.

Hismanoglu, Murat (2011). ,An Investigation of ELT Students' Intercultural Communicative Competence in Relation to Linguistic Proficiency, Overseas Experience and Formal Instruction". International Journal of Intercultural Relations 35 (6): 805817. https://doi.org/10.1016/j.ijintrel.2011.09.001

Jones, Barry. 2005. "Developing Cultural Awareness". In Issues in Modern Foreign Languages Teaching, edited by Kit Field, 151-162. Taylor \& Francis e-Library. 
Kirkpatrick, Andy. 2007. World Englishes: Implications for International Communication and English Language Teaching. Cambridge: Cambridge University Press.

Kramsch, Claire. 2001. Language and Culture. Oxford: Oxford University Press.

Kramsch, Claire. 2011. Language and Culture. In The Routledge Handbook of Applied Linguistics, edited by James Simpson, 305-317. Abingdon: Routledge.

Kramsch, Claire and Hua Zhu. 2016. "Language and Culture in ELT". In The Routledge Handbook of English Language Teaching, edited by Graham Hall, 38-50. Oxon: Routledge.

Larson-Hall, Jenifer. 2010. A Guide to Doing Statistics in Second Language Research Using SPSS. Oxon: Routledge.

Mair, Christian. 2013. „The World System of Englishes: Accounting for the Transnational Importance of Mobile and Mediated Vernaculars". English World-Wide 34: 253-278. https://doi.org/10.1075/eww.34.3.01mai

Maurer, Trent, W. 2013. „Evaluation of a Classroom Exercise on Social Distance and Discrimination". International Journal for the Scholarship of Teaching and Learning 7 (2). https://doi.org/10.20429/ijsotl.2013.070218

Mitchell, Rosamond, Nicole Tracy-Ventura and Kevin McManus, eds. 2015. Residence Abroad, Social Networking and Second Language Learning: Eurosla Monographs Series 4. Amsterdam: The European Second Language Association.

Moon, Dreama, Gail. 1996. „Concepts of 'culture': Implications for intercultural communication research". Communication Quarterly 44 (1): 70-84. https://doi. org/10.1080/01463379609370001

Pérez-Vidal, Carmen. 2017. "Study Abroad and ISLA". In The Routledge Handbook of Instructed Second Language Acquisition, edited by Shawn Loewen and Masatoshi Sato, 339-360. New York: Taylor \& Francis.

Scherger, Anna-Lena. 2019. "Dative case marking in 2L1 and L2 bilingual SLI". In Proceedings of Gala 2017: Language Acquisition and Development, edited by Pedro Guijarro-Fuentes and Cristina Suárez-Gómez, 95-115. Cambridge: Cambridge Scholars Publishing.

Schumann, John, H. 1978. "The Acculturation Model for Second Language Acquisition". In Second Language Acquisition and Foreign Language Teaching, edited by Rosario C. Gingras, 27-50. Arlington, VA: Center for Applied Linguistics.

Schumann, John, H. 1986. „Research on the acculturation model for second language acquisition". Journal of Multilingual and Multicultural Development 7: 379-392. https://doi.org/10.1080/01434632.1986.9994254

Scrivener, Jim. 2015. Learning Teaching: The Essential Guide to English Language Teaching ( $3^{\text {rd }}$ ed.). Oxford: Macmillan Education.

Seoane, Elena. 2016. World Englishes Today. In World Englishes: New Theoretical and Methodological Considerations, edited by Elena Seoane and Christina Suárez-Gómez, 1-15. Amsterdam/ Philadelphia: John Benjamins.

Thyne, Maree and Rob Lawson. 2001. "The Design of a Social Distance Scale to be Used in the Context of Tourism". In Asia Pacific Advances in Consumer Research Volume 4, edited by Paula M. Tidwell and Thomas E. Muller, 102-107. Provo, UT: Association for Consumer Research. 
Vuksanović, Gordana. 2004. „Bogardusova skala socijalnog odstojanja - prednosti i ograničenja”. Sociološki pregled 38: 309-320.

Wark, Colin and John F. Galliher. 2007. Emory Bogardus and the Origins of the Social Distance Scale. American Sociologist 38 (4): 383-395. https://www.jstor.org/ stable/27700519

Jelena V. Grubor

Državni univerzitet u Novom Pazaru

Departman za filološke nauke,

SP Engleski jezik i književnost

Kulturna dimenzija u usvajanju stranog jezika: Stavovi filološki- i nefilološki-orijentisanih srednjoškolaca i studenata prema govornicima engleskog jezika

Stavovi prema govornicima ciljnog jezika predstavljaju aspekt učenja stranog jezika koji odslikava kulturnu dimenziju ovog procesa. U skladu sa tim, glavni ciljevi ovog istraživanja su da se utvrde stavovi ispitanika prema Britancima i Amerikancima, kao i stepen socijalne distance koju ispitanici imaju prema ovim grupama, upoređivanjem razlika u stepenu spremnosti da se identifikuju sa govornicima ciljnog i svog jezika. Uzorak iz istraživanja $(\mathrm{N}=239)$ činile su dve starosne grupe (srednjoškolci i studenti), i dva obrazovna profila: filološki- i nefilološki-orijentisani ispitanici. Osnovni istraživački instrumenti činile su Bogardusova skala socijalne distance, koja je pokazala dobru internu konzistentnost na svim subskalama, i Skala kontakta sa engleskim jezikom, čiji je glavni cilj da utvrdi stvarnu interakciju ispitanika sa govornicima ciljnog jezika (dužinu boravka u govornim zajednicama ciljnog jezika, potencijalnu mobilnost u okviru školskih/univerzitetskih programa razmene i sl). Rezultati sugerišu da filološki-orijentisane grupe, koje su dosta bolje upoznate sa kulturom ciljnog jezika, mnogo pozitivnije procenjuju pripadnike ciljnog jezika i da su generalno spremnije da se identifikuju sa njima, čak i na najintimnijoj relaciji (nivou supružnika). Stoga su implikacije istraživanja za nastavu da je potrebno podsticati nastavnike da kontinuirano upoznaju učenike sa različitim kulturnim elementima ciljnog jezika i da nastoje da utiču na negovanje pozitivnih stavova prema ciljnom jeziku i kulturi. Najzad, sadašnje istraživanje nije uspelo da utvrdi da li kontakt sa stvarnim ljudima u poređenju sa ,imaginarnim“ govornicima ciljnog jezika koji su plod percepcije pravi razliku u stavovima.

Ključne reči: Bogardusova skala socijalne distance, engleski kao strani jezik, filološki- i nefilološki-orijentisane grupe, kultura i govornici ciljnog jezika, socijalna distanca 
La dimension culturelle dans l'acquisition d'une langue étrangère: les attitudes des lycéens et des étudiants d'orientation philologique et non-philologique à l'égard des locuteurs de l'anglais

Les attitudes à l'égard des locuteurs de la langue cible représentent un aspect de l'apprentissage d'une langue étrangère qui reflète la dimension culturelle de ce processus. C'est pourquoi les principaux objectifs de cette recherche sont de préciser les attitudes des interrogés à l'égard des Britanniques et les Américains, tout comme le degré de distance sociale entre les interrogés et ces groupes, au moyen d'une comparaison des différences de leur degré de disposition de s'identifier avec les locuteurs de la langue cible et de leur propre langue. L'échantillon de la recherche $(\mathrm{N}=239)$ est composé de deux groupes d'âge (lycéens et étudiants), et deux profils académiques: les interrogés d'orientation philologique et ceux d'orientation non-philologique. Les principaux instruments de recherche ont été l'échelle de distance sociale de Bogardus, qui a montré une bonne consistance interne sur toutes les sous-échelles, et l'échelle de contact avec l'anglais, dont l'objectif principal est de déterminer la vraie interaction des interrogés avec les locuteurs de la langue cible (la longueur de séjour dans les communautés linguistiques de la langue cible, la mobilité potentielle dans le cadre des programmes d'échange scolaires/universitaires etc.). Les résultats suggèrent que les groupes d'orientation philologique, qui sont bien mieux familiarisés avec la culture de la langue cible, évaluent bien plus positivement les locuteurs de la langue cible et qu'ils sont généralement plus disposés à s'identifier avec eux, même lorsqu'il s'agit d'une relation très proche (niveau des conjoints). Les implications de la recherche pour l'enseignement sont qu'il faut encourager les enseignants de faire continuellement connaître aux élèves les différents éléments culturels de la langue cible et s'efforcer d'influer sur le développement des attitudes positives à l'égard de la langue et de la culture cibles. Enfin, la recherche actuelle n'a pas réussi à définir si le contact avec de vraies personnes en comparaison avec des locuteurs "imaginaires" de la langue cible, le fruit de la perception, crée une différence dans les attitudes.

Mots clés: échelle de distance sociale de Bogardus, anglais comme langue étrangère, groupes d'orientation philologique et non-philologique, culture et locuteurs de la langue cible, distance sociale

Primljeno / Received: 13.06.2021

Prihvaćeno / Accepted for publication: 20.09.2021

Етноантрополошки проблеми, н.с. год. 16 св. 4 (2021) 